\title{
Studies of properties of rubber wood with impregnation of polymer
}

\author{
RASHMI R DEVI and T K MAJI* \\ Department of Chemical Sciences, Tezpur University, Tezpur 784 028, India
}

\begin{abstract}
Impregnation of rubber wood has been carried out under different conditions by using styrene as grafting monomer and glycidyl methacrylate (GMA) as crosslinker. Properties such as dimensional stability, water absorption, hardness, tensile strength, flexural strength, etc of the impregnated wood have been checked and found to be improved by incorporation of GMA as the crosslinker with styrene. The polymerimpregnated wood has also been characterized by FTIR spectroscopy and DSC.
\end{abstract}

Keywords. Wood; composite; crosslinker; polymers; styrene-glycidyl methacrylate.

\section{Introduction}

Wood, a renewable resource and naturally occurring material abundantly available has a wide range of applications as construction material, pulp, paper, fireboard products as well as source of energy and as raw materials for various industrially important chemicals. Two types of woods viz. hard and soft, are available. Softwood trees are lacking in strength, dimensional stability etc which restrict their uses. The softwood trees are generally used for fuel purposes. These softwoods can be converted into value added primary wood suitable for furniture, office equipment etc through impregnation with polymer in the capillaries, cavities, and void spaces of the wood cell.

Considerable work has been done on the modification of wood (Rowell 1983). Meyer (1981) reported that wood treated with vinyl type monomer followed by curing (radiation or catalyst) significantly improves the moisture resistance, hardness etc. Baki et al (1993) has shown that different types of wood impregnated with a polymer mixture containing macroionomer and styrene improves water repellency, compression and bending strength. Rozman et al (1998) reported that the use of glycidyl methacrylate as crosslinker with diallyl phthalate improves the dimensional stability compared to those based on diallyl phthalate alone. The composite prepared by wood and acrylic, vinyl type monomers show low dimensional stability in water. This may be due to the confinement of monomer in the cell lumen instead of cell wall (Rowell and Ellis 1998). Therefore, a system is sought which consists of a monomer that has the ability to penetrate into the cell wall and copolymerize with other monomers that can provide reaction sites for crosslinking. Rozman et al (1997) have observed an improvement in moisture resistance, mechanical properties etc of the wood when treated with glycidyl methacrylate and polymerized with diallyl phthalate.

\footnotetext{
*Author for correspondence
}

GMA is a difunctional monomer, containing a terminal $\mathrm{C}=\mathrm{C}$ and an epoxy group. It is able to react with wood hydroxyl group through its epoxy end. It may also be able to react with styrene through its double bond. It is assumed that styrene can react with GMA through its double bond. This present study reports the results of rubberwood treated with styrene with GMA as the crosslinker.

\section{Experimental}

\subsection{Materials}

Rubber wood was supplied locally. Styrene was used after purification and glycidyl methacrylate (GMA) was supplied by MERCK. The initiator used 2,2'-azobis2(-methylbutyronitrile) (AIBN) was obtained from the National Chemical Co. (India). All other chemicals and solvents used in this study were of analytical grade.

\subsection{Methods}

2.2a Sample preparation: The wood specimen used for testing were prepared from clear defect free rubber wood cut into blocks of $2.5 \times 2.5 \times 0.5 \mathrm{~cm}$ for dimensional stability, water absorption, hardness and chemical resistance tests.

For tensile strength measurements samples were prepared in several steps. The blocks were cut into $11.5 \times$ $20 \times 0.7 \mathrm{~cm}$ using the standard method (Schneider et al 1990). Half of the samples were shaped into a 'dog-bone' shape with a $8 \times 4 \mathrm{~mm}$ centre portion of $50 \mathrm{~mm}$ long, $25 \mathrm{~mm}$ of which would be the extensiometer gauge length. The other half of the samples was treated with polymer and then shaped. After that each sample was filled in the gauge length region (30 $\mathrm{mm}$ at specimen centre) with a fine, flat file to ensure an uniform rectangular cross section in the gauge length. Sample widths and thickness were 
measured at three places in the gauge length of each specimen and the values averaged to obtain cross-sectional area. Bending test samples were cut into blocks of $10 \times 1 \times 1 \mathrm{~cm}$.

2.2b Impregnation procedure: All samples were oven dried to constant weight of $105^{\circ} \mathrm{C}$ and the dimensions and weights were then measured. Samples were then placed into an impregnation chamber, which was evacuated to two ranges of vacuums 5" $\mathrm{Hg}$ and $10^{\prime \prime} \mathrm{Hg}$, respectively for five min. Some loads were applied on the samples before impregnation so that no flotation occurs. The appropriate monomer system was then introduced through a dropping funnel and the specimens were left immersed while atmospheric pressure was reached and then allowed for $4 \mathrm{~h}$ at room temperature for further impregnation. The samples were then taken out from the chamber and excess chemicals were wiped out from the surfaces. Specimens were then wrapped in Al foils and cured at $90^{\circ} \mathrm{C}$ for $24 \mathrm{~h}$. The samples were again oven dried at $105^{\circ} \mathrm{C}$ for $24 \mathrm{~h}$. The treated samples were then extracted with benzene to remove the homo polymers. The specimens were then dried and measured to determine polymer loading.

\section{Measurements}

\subsection{Dimensional stability and water absorption tests}

Dimensional stability of the samples were measured by measuring the volumetric swelling of the samples after placing in a water bath for $24 \mathrm{~h}$ at room temperature and chemical resistance test of the samples by the same procedure in $4 \% \mathrm{NaOH}$ and $\mathrm{CH}_{3} \mathrm{COOH}$ (glacial), respectively.

Water absorption test was measured by measuring the weights increased after $24 \mathrm{~h}$ dipping in a water bath.

Volumetric swelling was considered as change in volume expressed as percentage of the volume of the dry heated specimen.

\subsection{Mechanical properties}

3.2a Hardness: Hardness was measured in a Durometer (Hiroshima) measured according to ASTM D2240 method expressed as ShoreD hardness.

3.2b Tensile strength: Tensile strength was measured in Zwick Testing machine (Z010 model) with a crosshead speed of $2 \mathrm{~mm} / \mathrm{min}$.

3.2c Bending test: Bending test was performed in Zwick Testing machine (Z010 model) according to ASTM D790 with a crosshead speed of $2 \mathrm{~mm} / \mathrm{min}$. 3.2d FTIR: IR study was performed using a Nicolet FTIR spectrophotometer (Impact 410) using $\mathrm{KBr}$ pellets.

3.2e DSC: DSC study was carried out by using a DSC analyser with Mettler Toledo Star system under $\mathrm{N}_{2}$ atmosphere at initial scan from $50^{\circ} \mathrm{C}$ to $150^{\circ} \mathrm{C}$ to remove the thermal history effects, then cooled to $50^{\circ} \mathrm{C}$ and the data collected at $10^{\circ} \mathrm{C} / \mathrm{min}$ to $225^{\circ} \mathrm{C}$. Typical sample size was $6.5 \mathrm{mg}$.

\section{Results and discussion}

\subsection{Effect of variation of vacuum}

The percentage of polymer loading was checked at two levels of vacuum i.e. 5" $\mathrm{Hg}$ and $10^{\prime \prime} \mathrm{Hg}$ (table 1). Polymer loading was found better at $5^{\prime \prime} \mathrm{Hg}$. Therefore, all the successive experiments were performed at that level of vacuum.

\subsection{Variation of catalyst concentration and concentra- tion of monomers}

Table 2 shows the results of variation of monomer concentration and catalyst concentration. Wood-styreneGMA combination showed better results (higher polymer loading) compared to wood-styrene system, while woodGMA system showed highest loading. This might be due to increased interaction of GMA with styrene and wood

Table 1. Effect of variation of vacuum on polymer loading (\%) (catalyst (AIBN) with $0.5 \%$ concentration) on rubber wood.

\begin{tabular}{lcllc}
\hline \multicolumn{2}{c}{ Sample particulars (ratio) } & & \multicolumn{2}{c}{ Vacuum* $(\mathrm{Hg})$} \\
\cline { 1 - 2 } \cline { 5 - 5 } Styrene & GMA & & $5^{\prime \prime}$ & $10^{\prime \prime}$ \\
\hline 100 & 20 & & $49 \cdot 82$ & $35 \cdot 0$ \\
00 & 0 & & $33 \cdot 28$ & - \\
0 & 100 & & $93 \cdot 0$ & - \\
\hline
\end{tabular}

*All the data were taken from average of five samples.

Table 2. Variation of styrene/GMA and catalyst concentration on polymer loading (\%) (vacuum: 5" Hg).

\begin{tabular}{rrrrrrr}
\hline & & & \multicolumn{3}{c}{$\begin{array}{c}\text { Catalyst concentration* } \\
\text { (by weight) }\end{array}$} \\
\cline { 1 - 3 } \cline { 5 - 6 } Wood & Styrene & GMA & & 0.5 & 2 & 5 \\
\hline 100 & 0 & & $33 \cdot 28$ & - & - \\
100 & 20 & & 49.82 & $15 \cdot 33$ & $21 \cdot 22$ \\
0 & 100 & & 93.0 & - & - \\
\hline
\end{tabular}

*All values were taken from average of five samples. 
Table 3. Effect of polymer loading on various properties of rubber wood.

\begin{tabular}{|c|c|c|c|c|c|}
\hline \multirow[b]{2}{*}{ Properties } & \multirow[b]{2}{*}{ Untreated } & \multirow{2}{*}{$\begin{array}{l}\text { Treated with styrene } \\
\quad(0.5 \% \text { cat })\end{array}$} & \multicolumn{3}{|c|}{$\begin{array}{l}\text { Treated with styrene-GMA } \\
\text { (\% catalyst) }\end{array}$} \\
\hline & & & $0.5 \%$ & $2 \%$ & $3 \%$ \\
\hline Loading & - & $33 \cdot 28$ & $49 \cdot 82$ & $15 \cdot 86$ & $21 \cdot 15$ \\
\hline Hardness & $46 \cdot 57$ & $61 \cdot 98$ & $61 \cdot 5$ & $60 \cdot 34$ & 65.98 \\
\hline $\begin{array}{l}\% \text { Volume increase after } \\
\text { dipping in water }(24 \mathrm{~h})\end{array}$ & $10 \cdot 65$ & $6 \cdot 13$ & $7 \cdot 83$ & - & $10 \cdot 33$ \\
\hline $\begin{array}{l}\text { Water absorbed (after } \\
24 \mathrm{~h} \text { dipping) } \\
\% \text { Swelling (after } 24 \mathrm{~h} \\
\text { dipping) in }\end{array}$ & $66 \cdot 67$ & $37 \cdot 28$ & $20 \cdot 0$ & $53 \cdot 13$ & $40 \cdot 48$ \\
\hline I. Acetic acid (glacial) & $6 \cdot 07$ & $12 \cdot 97$ & $3 \cdot 38$ & $8 \cdot 86$ & $13 \cdot 48$ \\
\hline II. $4 \% \mathrm{NaOH}$ & $8 \cdot 45$ & $15 \cdot 73$ & $4 \cdot 35$ & $5 \cdot 34$ & $8 \cdot 08$ \\
\hline
\end{tabular}

Table 4. Mechanical properties of treated rubber wood.

\begin{tabular}{lccccccc}
\hline $\begin{array}{l}\text { Sample } \\
\text { parameters }\end{array}$ & $\begin{array}{c}\text { Nature } \\
\text { of test }\end{array}$ & $\begin{array}{c}E \text {-modulus } \\
(\mathrm{MPa})\end{array}$ & $\begin{array}{c}F_{\max } \\
(\mathrm{MPa})\end{array}$ & $\begin{array}{c}\text { Deflection at } \\
F_{\max }(\%)\end{array}$ & $\begin{array}{c}\mathrm{RB} \\
(\mathrm{MPa})\end{array}$ & $\begin{array}{c}\text { Break load } \\
(\mathrm{MPa})\end{array}$ & $\begin{array}{c}\text { Tensile stress } \\
(\mathrm{MPa})\end{array}$ \\
\hline Untreated & Bending & 2816.43 & $60 \cdot 13$ & 1.57 & - & $60 \cdot 13$ & - \\
Styrene & $\#$ & 6718.49 & 97.91 & 1.32 & - & 97.91 & - \\
Styrene-GMA & $"$ & 7140.93 & 104.01 & 1.48 & - & 104.01 & - \\
Untreated & Tensile & 2252.59 & $57 \cdot 12$ & - & $57 \cdot 12$ & - & $57 \cdot 12$ \\
\hline
\end{tabular}

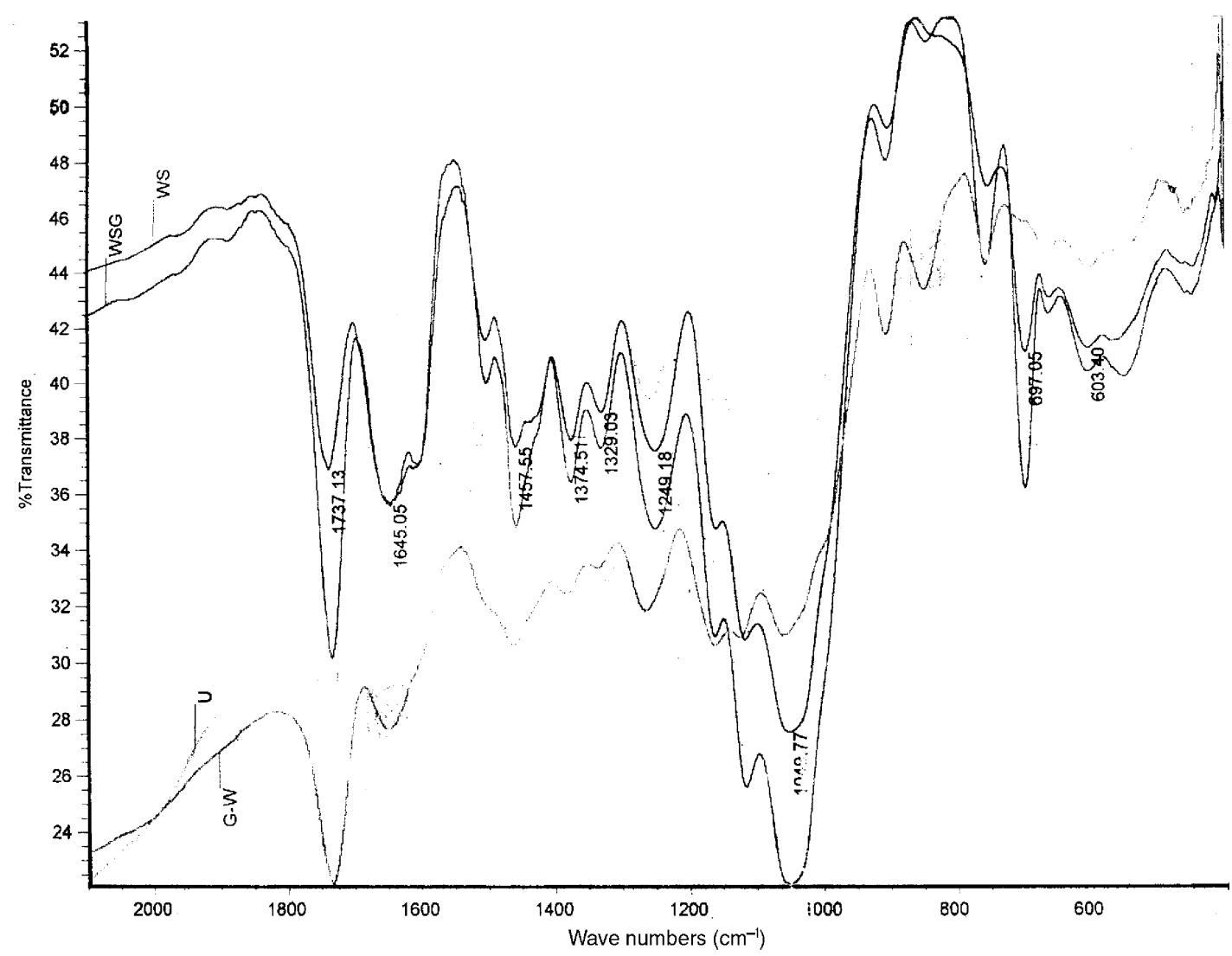

Figure 1. IR spectra of U, untreated; GW, GMA treated; WSG, styrene-GMA treated and WS, styrene treated rubber wood. 

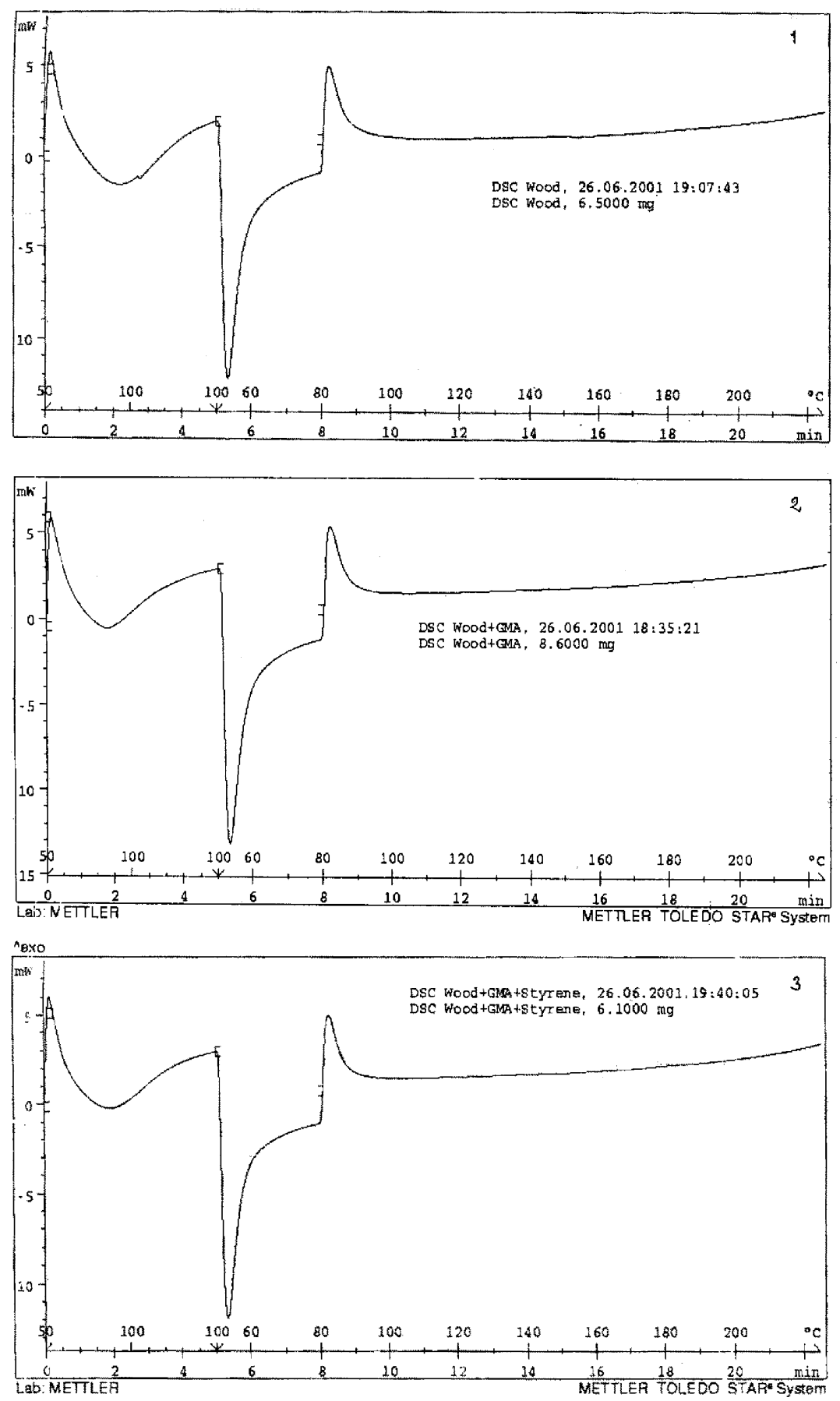

Figure 2. The DSC results of the 1. untreated, 2. GMA treated and 3. styrene-GMA treated wood.

through the epoxy group and the double bond. Loading was found to be decreased initially on increasing catalyst concentration, but again increased on further increase of catalyst concentration.

\subsection{Effect of polymer loading on various properties of rubber wood}

Different physical parameters of some of the selected polymer loaded samples are shown in table 3 . All the samples were found to be more or less better compared to those of either untreated wood or styrene treated wood. Water absorption was found to be decreased remarkably for wood-styrene-GMA system. The results showed that styrene alone was not able to penetrate properly into the cell wall. But in combination with GMA it was able to penetrate into the cell wall more as compared to styrene due to the advantageous molecular size (Rozman et al 1995). 


\subsection{Mechanical properties}

Table 4 shows the mechanical properties of rubber wood (untreated and treated ones). The properties were found to be improved after impregnation. Modulus of elasticity, $F_{\text {max }}$, was found to be increased for styrene-GMA treated one compared to untreated or styrene treated one (bending strength). Tensile strength of the untreated samples is shown in table 4.

\subsection{IR study}

Figure 1 shows the results of the IR-analysis of treated and untreated wood. Interaction between wood-styreneGMA was also confirmed by FTIR spectroscopy (Rozman et al 1997; Pandey 1999) which showed an enhanced peak at $1733 \mathrm{~cm}^{-1}$ in the carbonyl region after the reaction with GMA. The peak (around $1457 \mathrm{~cm}^{-1}$ ) which may be due to $\mathrm{C}-\mathrm{H}$ deformation (methyl and methylene) was found to increase in the case of styrene-GMA treated samples compared to untreated or styrene treated samples. But the peak at $1429 \mathrm{~cm}^{-1}$ which is due to $\mathrm{C}-\mathrm{H}$ plane deformation with aromatic ring stretching was found to decrease as one passes from untreated wood to styrene treated one and further decreased to styreneGMA treated wood. The peak around $1610 \mathrm{~cm}^{-1}$, which is due to aromatic skeletal vibration and carbonyl stretching, was found to be more pronounced in the case of styrene-GMA treated samples and styrene treated one compared to that of untreated one.

\subsection{DSC study}

Figure 2 shows the DSC results of the treated and untreated wood. DSC results showed no distinct phase change of the treated samples. If there were chemical bonding, some phase change may occur, which however, cannot on the basis of these data, conclude that there is no chemical bonding between wood-styrene-GMA. Similar findings were reported by Simonsen et al.

\section{Conclusion}

From the results it can be concluded that wood-styreneGMA combination shows better performance in terms of mechanical and other properties compared to those of either untreated or wood-styrene combination. Although DSC results did not give any significant results, but the interaction between wood, GMA and styrene was confirmed by the IR results. Further investigation will reveal the picture clearly.

\section{Acknowledgements}

The authors gratefully acknowledge financial assistance from the Council of Scientific and Industrial Research, New Delhi. The authors are also grateful to Md. Ilias Ali who has helped in the mechanical testing of the samples.

\section{References}

Baki H, Yalcin O and Hakki A 1993 J. Appl. Polym. Sci. 47 1097

Meyer J A 1981 Wood Sci. 1449

Pandey K K 1999 J. Appl. Polym. Sci. 711969

Rowell R M 1983 Forest Products (Abstr.) 363

Rowell R M and Ellis W D 1998 Wood Fibre 10104

Rozman H D, Banks W B and Landler M L 1995 J. Appl. Polym. Sci. 571291

Rozman H D, Kumar R N, Abdul Khalil H P S, Abusamah A, Abu R and Ismail H 1997 Eur. Polym. J. 331213

Rozman H D, Kumar R N, Abusamah A and Saad M J 1998 J. Appl. Polym. Sci. 671221

Schneider Marc H, Phillips J G, Tingly D A and Barber R I 1990 Forest Products J. 4037

Simonsen J, Jacobson R and Rowell R 4th Int. conf. on woodfibre-plastic composite p. 215 